\title{
PERBANDINGAN KEMAMPUAN PENALARAN MATEMATIS SISWA DALAM PEMBELAJARAN MATEMATIKA DENGAN STRATEGI REACT DAN STRATEGI KONVENSIONAL
}

\author{
Haryuni Helmi' ${ }^{1}$, Irfan Arsid ${ }^{2}$ \\ ${ }^{1}$ SMP Negeri 7 Barru \\ ${ }^{2}$ Pendidikan Matematika, FKIP, Universitas Pancasakti Makassar \\ ryuni02@gmail.com, irfanarsid988@gmail.com
}

\begin{abstract}
ABSTRAK
Penelitian ini bertujuan untuk mengetahui perbandingan kemampuan penalaran matematis siswa (berupa nilai pre tes dan pos tes) siswa kelas X Air Frame kelas kontrol menggunakan pembelajaran dengan strategi konvensional dan kelas X Avionic kelas eksperimen menggunakan pembelajaran dengan strategi react dalam pokok bahasan Matriks. Jenis penelitian ini adalah eksperimen. Data penelitian dikumpulkan melalui observasi, tes, dan angketjenis penelitian ini dilaksanakan dengan menggunakan rancangan penelitian dua kelompok sampel yang terdiri dari kelas kontrol dan kelas eksperimen. Kelas eksperimen menggunakan pembelajaran dengan strategi react sedangkan kelas kontrol menggunakan pembelajaran dengan strategi konvensional. Penelitian ini dilakukan pada ttahun 2014 dengan melakukan proses belajar mengajar di kelas X Air Frame dan kelas X Avionic semester genap SMK Penerbangan Hasanuddin Makassar.Hasil penelitian dengan judul Perbandingan Kemampuan Penalaran Matematis Siswa Kelas X Avionic SMK Penerbangan Hasanuddin Makassar dalam Pembelajaran Matematika dengan Strategi React dan Strategi Konvensional dalam Memecahkan Masalah Berkaitan dengan Matriks dapat dikatakan terjadi perbedaan yang signifikan antara kelas kontrol dan kelas eksperimen, ini terlihat pada uji t yang dilakukan pada hasil gain kelas kontrol dan eksperimen Asym. Sig(2-tailed) $=0,000$. Jika diambil = 0,00 maka Asymp.Sig(2-tailed) $<0,05$ sehingga Ho ditolak. Dari pre tes dan pos tes setelah dilakukan uji man-whitney pada pre tes dan uji $t$ pada pos tes memperoleh nilai Sig. (2-tailed) sebesar 0,00 sehingga 1/2 Sig. (2-tailed) $<0,05$ sehingga dapat ditarik kesimpulan bahwa kemampuan bernalar matematis kelas eksperimen lebih baik daripada kelas kontrol. Pembelajaran matematika dengan menggunakan strategi REACT mendapat respon yang lebih baik daripada metode konvensional.
\end{abstract}

Kata kunci: strategi React, kemampuan penalaran

\begin{abstract}
This study aims to compare the students' mathematical reasoning abilities (such as the pre test and post test) the second class of Air Frame as the control class using conventional learning strategies and the second class of Avionics as experimental class using REACT learning strategy in the matrix subject. This type of research is experimental. Data were collected through tests and questionnaires. This type of research carried out by using a study design consisting of two groups of samples, the control class and experimental class. Experimental classes using REACT strategy, and the control classes using conventional strategies. This study was conducted on 2014 with the teaching and learning process in second class of Air Frame and Avionics SMK Penebangan Hasanuddin Makassar. The results of the study entitled Comparison Of Mathematical Reasoning Ability Second Class Of Avionics SMK Penerbangan Hasanuddin Makassar In Learning Mathematics React
\end{abstract}


Strategy and Conventional Strategy In The Matter Relating To Solve The Matrix can be said that there was significant difference between the experimental class and the control class, is seen on the t test performed on the results of the control and experimental classes gain Asym. Sig (2-tailed) = 0.000. If taken then Asymp.Sig $=0.00$ (2-tailed) $<0.05$ thus Ho is rejected. From the pre-test and post test after the man-whitney test on pre-test and t-test to post test to obtain the value of Sig. (2-tailed) of 0.00 so that $1 / 2$ Sig. (2-tailed) $<0.05$ so it can be concluded that the ability to reason mathematically experimental class are better than the control class. Learning math by using REACT strategy gets a better response than the learning of mathematics by using a conventional strategy.

\section{Key Word: React Strategy, Reasoning Abilities}

\section{A. Pendahuluan}

Matematika merupakan ilmu dasar yang penting untuk dipelajari, karena pola pikir matematika dapat membantu siswa berpikir logis, analitis, sistematis, kritis, dan kreatif, serta mampu bekerja sama. Melalui pola pikir matematika, diharapkan siswa sanggup menghadapi berbagai perubahan dalam kehidupan yang selalu berkembang.

Pada masa-masa lalu dan sampai detik ini, tidak sedikit orang tua dan orang awam yang beranggapan bahwa matematika dapat digunakan untuk memprediksi keberhasilan seseorang. Menurut mereka, jika seorang siswa berhasil mempelajari matematika dengan baik maka ia diprediksi akan berhasil juga mempelajari mata pelajaran lain. Begitu juga sebaliknya, seorang anak yang kesulitan mempelajari matematika akan kesulitan juga mempelajari mata pelajaran lain.

Matematika bukan hanya membentuk pola pikir siswa saja, tapi matematika bisa menyempurnakan ilmu yang lainnya. Hal inilah yang membuat matematika menjadi pelajaran wajib disekolah dari jenjang sekolah dasar samapai sekolah menengah atas. Matematika juga ditetapkan pemerintah sebagai salah satu mata pelajaran yang menentukan kelulusan siswa.

Matematika terbentuk sebagai hasil pemikiran manusia yang berhubungan dengan ide proses dan penalaran. matematika adalah penalaran, tidak mungkin seseorang bermatematika atau doing mathematics tanpa bernalar. Dengan kata lain matematika dan penalaran tidak bisa dipisahkan. Serta, kemampuan bernalar matematis merupakan bagian dari penalaran. Penalaran mencakup berpikir dasar, bernalar matematis dan berpikir kreatif.

Kemampuan bernalar matematis dapat diperoleh dari berbagai disiplin ilmu salah satu diantaranya adalah disiplin ilmu matematika, diharapkan pembelajaran matematika dapat meningkatkan kemampuan bernalar matematis siswa. Kemampuan bernalar matematis dapat digunakan dalam mengungkapkan suatu hal yang keliru dan suatu permasalahan yang salah. Bernalar matematis juga dapat membantu seseorang memperoleh pengetahuan, membuktikan suatu teori, dan memperkuat argumen.

Kemampuan bernalar seseorang dalam suatu bidang studi tidak dapat terlepas dari pemahamannya terhadap materi bidang studi tersebut. Kemempuan bernalar dalam suatu bidang studi hanya dapat dilakukan dengan mengetahui isi bidang studi tersebut. Dengan demikian agar siswa dapat bernalar dalam matematika, maka dia harus memahami matematika dengan baik.

Namun seperti yang kita ketahui bahwa matematika merupakan pelajaran yang bersifat aksiomatik, abstrak, formal, dan deduktif, sehingga banyak siswa yang menganggap matematika pelajaran yang sulit. Olehnya itu sikap positif siswa terhadap matematika dan proses pembelajarannya juga perlu diperhatikan. Hal ini penting karena sikap positif siswa terhadap 
matematika berkorelasi positif dengan prestasi belajar matematika. Sikap siswa terhadap matematika erat kaitannya dengan minat siswa terhadap matematika, maka ia akan dapat mengikuti proses pembelajarannya dengan baik dan suka mengerjakan tugas-tugas matematika.

Menurut hasil diskusi dengan guru matematika SMK Penerbangan Hasanuddin, strategi yang digunakan dalam pembelajaran matematika adalah strategi konvensional, dimana guru hanya menjelaskan materi, kemudian memberikan tugas kepada siswa. Interaksi yang terjadi seperti tanya jawab antara guru dan siswa jarang dilakukan sehingga kesempatan siswa untuk menemukan dan membangun pengetahuannya sendiri tidak ada. Sebagian besar siswa tampak mengerti dengan baik setiap penjelasan atau informasi dari guru, siswa jarang mengajukan pertanyaan pada guru sehingga guru aktif sendiri menjelaskan apa yang telah disiapkannya. Siswa hanya menerima saja apa yang telah disiapkan oleh guru. Selain itu para siswa juga sangat tidak mampu mengerjakan soal-soal yang berbentuk soal cerita apa lagi yang berkaitan dengan penarikan kesimpulan (bernalar)

Berdasarkan hal tersebut, kemudian muncul pertanyaan, metode, pendekatan atau strategi seperti apa yang dapat melatih kemampuan siswa dalam benalar, melibatkan aktivitas siswa secara optimal, dan membuat pembelajaran matematika menjadi lebih bermakna dan menyenangkan. Salah satu bentuk pembelajaran alternatif yang dirancang sedemikian rupa sehingga mencerminkan keterlibatan siswa secara aktif adalah melalui strategi REACT (relating, experiencing, applying, cooperating, transferring). Strategi ini merupakan strategi pembelajaran dengan pendekatan kontekstual. Strategi REACT merupakan strategi dalam pembelajaran kontekstual dimana terdapat 5 strategi yaitu Relating, Experiencing, Applying, Cooperating, dan Transferring. Selanjutnya Crawford menjelaskan tentang lima langkah strategi tersebut yaitu Strategi REACT (Relating, Experiencing, Applying, Cooperating, Transfering) adalah strategi pembelajaran yang ada dalam pembelajaran kontekstual, dimana di dalam pembelajaran ini terdapat lima langkah yaitu,

(1) Relating adalah pembelajaran yang dimulai dengan cara mengaitkan konsep-konsep baru yang akan dipelajari dengan konsep-konsep yang telah dipelajari,

(2) Experiencing adalah pembelajaran yang membuat siswa belajar dengan melakukan kegiatan matematik melalui eksplorasi, pencarian, dan penemuan,

(3) Applying adalah pembelajaran yang membuat siswa mengaplikasikan konsep,

(4) Cooperating saling berbagi, saling merespon, dan berkomunikasi dengan sesama teman, sedangkan

(5) Transferring adalah pembelajaran yang menggunakan pengetahuan baru didapatkan kedalam situasi yang baru.

Melalui pembelajaran ini diharapkan mampu meningkatkan kemampuan bernalar siswa SMK karena pada saat proses relating siswa diharapkan mampu memberikan penjelasan yang sederhana, dimana penjelasan itu akan mendorong siswa mengeluarkan ide-idenya. Ide-ide tersebut dapat dimanfaatkan untuk membangun keterampilan dasar siswa saat siswa melakukan experiencing. Supaya siswa mampu membuat kesimpulan yang baik, siswa bisa melakukannya dalam kelompok. Saat berdiskusi, siswa diharapkan mampu memberikan penjelasan yang lebih lanjut dan mengatur stategi dan taktik dalam mengaplikasikan konsep yang sedang dipelajari apllying dan transferring.

Karena itu, penulis tertarik ingin melihat sejauh mana pencapaian kemampuan benalar siswa dalam pembelajaran matematika dengan menggunakan strategi REACT, yang dituangkan dalam judul penelitian "Perbandingan Kemampuan Penalaran Matematis Siswa Kelas X Avionic 
SMK Penerbangan Hasanuddin Makassar Dalam Pembelajaran Matematika Dengan Strategi REACT dan Strategi Konvensional Dalam Memecahkan Masalah Berkaitan Dengan Matriks".

Berdasarkan latar belakang masalah yang telah diuraikan di atas, maka permasalah dalam penelitian ini dapat dirumuskan sebagai berikut:

1. Apakah kemampuan penalaran matematis siswa pada pembelajaran matematika dengan strategi REACT lebih baik daripada siswa yang mendapat pembelajaran matematika dengan strategi konvensional?

2. Bagaimana pencapaian kemampuan penalaran matematis siswa yang mendapat pembelajaran matematika dengan strategi REACT dan strategi konvensional?

3. Bagaimana respon siswa terhadap pembelajaran matematika dengan strategi REACT dan strategi konvensional?

Berdasarkan rumusan masalah di atas, maka tujuan yang ingin dicapai dalam penelitian ini adalah sebagai berikut.

1. Mengetahui apakah kemampuan penalaran matematis siswa pada pembelajaran matematika dengan strategi REACT lebih baik daripada siswa yang mendapat pembelajaran matematika dengan strategi konvensional?

2. Mengetahui pencapaian kemampuan penalaran matematis siswa yang mendapat pembelajaran matematika dengan strategi REACT dan strategi konvensional.

3. Mengetahui bagaimana respon siswa terhadap pembelajaran matematika dengan strategi REACT dan strategi konvensional.

\section{B. METODE}

Metode yang digunakan dalam penelitian ini adalah metode eksperimen, sebab dalam penelitian ini diberikan suatu perlakuan untuk mengetahui hubungan antara perlakuan tersebut dengan aspek tertentu yang akan diukur. Penelitian eksperimen atau percobaan (experimental research) adalah penelitian yang benar-benar untuk melihat hubungan sebab-akibat. Perlakuan yang kita lakukan terhadap variabel bebas kita lihat hasilnya pada variabel terikat.

Dalam penelitian ini perlakuan yang diberikan adalah pembelajaran melalui strategi REACT, sedangkan aspek yang diukurnya adalah penalaran matematis siswa. Olehnya itu, yang menjadi variabel bebas dalam penelitian ini adalah pembelajaran dengan strategi REACT dan variabel terikatnya adalah penalaran matematis.

Tabel 1 Desain penelitian

\begin{tabular}{cccc}
\hline Kelompok & Tes Awal & Perlakuan & Tes Akhir \\
\hline Eksperimen & TE 1 & XE & TE 2 \\
Kontrol & TK 1 & XK & TK 2 \\
\hline
\end{tabular}

Keterangan :

TE 1 : Tes awal yang diberikan kepada siswa dalam kelompok eksperimen

TK 1 : Tes awal yang diberikan kepada siswa dalam kelompok kontrol

XE : Proses belajar mengajar matematika berdasarkan pada strategi REACT

XK : Proses belajar mengajar matematika berdasarkan pada strategi konvensional

TE 2 : Tes akhir yang diberikan kepada siswa dalam kelompok eksperimen

TK 2 : Tes akhir yang diberikan kepada siswa dalam kelompok kontrol

Unit experimen dalam penelitian ini adalah siswa SMK Penerbangan Hasanuddin kelas X sebanyak dua kelas, yang terdiri atas kelas eksperimen dan kelas kontrol. Kedua kelas tersebut diambil secara acak dari tiga kelas yang ada. Kelas eksperimen merupakan kelas 
yang mendapatkan pembelajaran dengan strategi REACT sedangkan kelas kontrol adalah kelas yang mendapatkan pembelajaran dengan strategi konvensional.

Penelitian ini dilaksanakan di kelas X SMK Penerbangan Hasanuddin Makassar pada bulan januari 2020. Adapun instrument yang digunakan dalam penelitian ini adalah tes berupa soal uraian dan non tes berupa angket respon dan lembar observasi. Dalam penelitian ini dilakukan 4 tahap, yakni tahap persiapan, tahap penelitian, tahap analisis dan penyusunan hasil penelitian, dan tahap penyusunan kesimpulan.

Data yang diperoleh dalam penelitian ini terdiri dari data kuantitatif dan data kualitatif. Data kuantitatif diperoleh dari data hasil pretes dan postes, sedangkan data kualitatif diperoleh dari data pada lembar observasi, dan angket respon siswa. Data-data tersebut dikumpulkan untuk kemudian dilakukan pengolahan data.

Pre tes dan pos tes dilakukan dengan tujuan untuk mengetahui sejauh mana peningkatan kemampuan bernalar siswa. Pada lembar observasi, terdapat lembar observasi untuk siswa dan guru. Lembar observasi ini digunakan untuk mengetahui aktivitas siswa dan guru selama pembelajaran berlangsung. Lembar observasi ini diisi oleh observer. sedangkan angket digunakan untuk melihat sejauh mana sikap siswa terhadap pembelajaran yang telah dilakukan dengan menggunakan strategi REACT.

Data yang dikumpulkan dalam penelitian ini mencakup (1) Hasil pekerjaan siswa yang diberikan peneliti dalam menyelesaikan soal-soal tentang materi fungsi yang meliputi LKS di setiap proses pembelajaran/pertemuan yang dikerjakan secara individual yang diberikan disetiap akhir pertemuan sebanyak tiga kali. LKS I diberikan setelah selesai pertemuan I (di akhir pertemuan pertama), LKS II pada akhir pertemuan kedua, LKS III pada akhir pertemuan ketiga. (2) Hasil pengamatan terhadap langkah-langkah pembelajaran dan suasana kelas pada saat pembelajaran berlangsung. (3) Catatan lapangan selama proses pelaksanaan penelitian yang diperoleh dari hasil pengamatan oleh guru yang melaksanakan tindakan pembelajaran di SMK Penerbangan Hasanuddin Makassar. Dan (4) hasil angket respon siswa terhadap kegiatan pembelajaran pada lembar respon yang disertai saran-saran untuk perbaikan ke depan.

Sumber data dalam penelitian ini kelas X Avionic SMK Penerbangan Hasanuddin Makassar.

Data yang terkumpul kemudian dianalisis dengan menggunakan teknik analisis deskriptif dan inferensial. Untuk analisis kuantitatif digunakan statistik deskriptif, yaitu skor rata-rata dan presentase, frekuensi, dan persentase nilai terendah dan nilai tertinggi yang dicapai siswa.

Data hasil belajar yang diperoleh dikategorikan berdasarkan KKM (Kriteria Ketuntasan Minimal) SMK Penerbangan Hasanuddin Makassar yaitu:

Tabel 2 KKM SMK Penerbangan Hasanuddin Makassar

\begin{tabular}{cc}
\hline Skor & Kategori \\
\hline$<75$ & Tidak tuntas \\
$\geq 75$ & Tuntas \\
\hline
\end{tabular}

Kemudian untuk analisis kualitatif digunakan lembar observasi untuk mengetahui perubahan sikap siswa, keaktifan siswa, kerajianan siswa dan keterampilan siswa. 
Untuk melihat kualitas peningkatan kemampuan bernalar siswa diperoleh dari skor gain ternormalisasi (indeks gain). Analisis terhadap skor gain ternormalisasi dilakukan dengan menggunakan rumus indeks gain sebagai berikut:

$$
\text { Indeks Gain }=\frac{\text { Skor Postes }- \text { Skor Pretes }}{\text { SMI }- \text { Skor Pretes }}
$$

Skor indeks gain $(\mathrm{g})$ tersebut diinterpretasikan dengan menggunakan kriteria yang diungkapkan oleh Hake pada tabel 3.3.

\section{Tabel 3 Kriteria Normalized Gain (Indeks Gain)}

\begin{tabular}{cc}
\hline Indeks Gain $(\boldsymbol{g})$ & Kriteria \\
\hline$g>0,7$ & Tinggi \\
$0,3<g \leq 0,7$ & Sedang \\
$g \leq \mathbf{0 , 3}$ & Rendah \\
\hline
\end{tabular}

Untuk melihat kemampuan bernalar siswa dalam setiap indikator kemampuan bernalar siswa, hasil postes siswa dianalisis dengan cara mengelompokkan indikator kemampuan bernalar ke dalam 4 kelompok yaitu memberikan penjelasan sederhana dengan memfokuskan pertanyaan, memberikan penjelasan sederhana dengan menjawab pertanyaan tentang suatu tantangan, menarik kesimpulan dengan membuat deduksi dan mempertimbangkan hasil deduksi, dan mengatur strategi dan taktik dengan memutuskan suatu tindakan. Kemudian dihitung persentasenya dan diinterpretasikan.

Data dari hasil lembar observasi merupakan data pendukung dalam penelitian ini. Lembar observasi dan catatan lapangan dianalisis untuk memeriksa totalitas penerapan strategi REACT dalam pembelajaran matematika. Hal-hal yang terlewat pada proses pembelajaran yang telah dilakukan dievaluasi dan direfleksikan pada proses pembelajaran berikutnya.

Angket diberikan dengan tujuan untuk mengetahui sikap siswa terhadap matematika dan pembelajarannya secara umum, terhadap pembelajaran matematika dengan menggunakan strategi REACT, dan terhadap bahan ajar yang diberikan. Pernyataan pada angket terbagi menjadi dua pernyataan yaitu pernyataan positif dan negatif. Pernyataan ini dibuat berdasarkan aspek-aspek yang diteliti. Aspek tersebut meliputi sikap siswa terhadap pelajaran matematika, sikap siswa terhadap pembelajaran matematika dengan menerapkan strategi REACT, dan sikap siswa terhadap tes kemampuan bernalar matematis.

Data angket disajikan dalam bentuk tabel dengan tujuan untuk memudahkan dalam membaca data, frekuensi dan persentase masing-masing jawaban. Untuk mengetahui persentase jawaban siswa pada setiap pernyataan, angket siswa dihitung dengan rumus perhitungan persentase sebagai berikut:

Keterangan:

$$
P=\frac{F}{n} \times 100 \%
$$

$P=$ Persentase jawaban

$F=$ Frekuensi jawaban

$n=$ Banyaknya responden

Persentase yang diperoleh ditafsirkan berdasarkan kriteria pada halaman selanjutnya tabel 3.4:

Tabel 4 Interpretasi Jawaban Angket Siswa 


\begin{tabular}{cc}
\hline Persentase Jawaban & Interpretasi \\
\hline $0 \%$ & Tak seorang pun \\
$1 \%-24 \%$ & Sebagian kecil \\
$25 \%-49 \%$ & Hampir setengahnya \\
$50 \%$ & Setengahnya \\
$51 \%-74 \%$ & Sebagian besar \\
$75 \%-99 \%$ & Hampir seluruhnya \\
$100 \%$ & seluruhnya \\
\hline
\end{tabular}

Setelah data angket tersebut diinterpretasikan, data tersebut diolah dengan menghitung rata-rata skor angket setiap siswa.

Lembar Observasi dijadikan sebagai data pendukung dalam penelitian ini. Agar memudahkan dalam menginterpretasinya, penyajian lembar observasi dibuat ke dalam bentuk tabel.

Menguji normalitas data hasil pretes dan hasil postes kelas eksperimen dan kelas kontrol dengan tujuan untuk mengetahui apakah data skor pretes sampel berasal dari populasi yang berdistribusi normal dengan bantuan software SPSS. Uji normalitas yang digunakan dalam penelitian ini adalah uji Shapiro-Wilk dengan taraf signifikansi 5\%. Hal ini dikarenakan sampel yang digunakan dalam penelitian ini berukuran 40 (lebih dari 30) dan tergolong kelompok besar. Perumusan hipotesis yang digunakan pada uji normalitas data pretes adalah sebagai berikut:

H0 : Skor pretes (kelas eksperimen atau kelas kontrol) berasal dari populasi yang berdistribusi normal.

H1 : Skor pretes (kelas eksperimen atau kelas kontrol) berasal dari populasi yang tidak berdistribusi normal.

Sedangkan perumusan hipotesis yang digunakan pada uji normalitas data postes adalah sebagai berikut:

HO : Skor postes (kelas eksperimen atau kelas kontrol) berasal dari populasi yang berdistribusi normal.

H1 : Skor postes (kelas eksperimen atau kelas kontrol) berasal dari populasi yang tidak berdistribusi normal.

Dengan menggunakan taraf signifikansi 0,05 maka kriteria pengujiannya adalah: Nilai signifikansi (sig.) atau nilai probabilitas $<0,05$, maka Distribusi adalah tidak normal. Nilai signifikansi (sig.) atau nilai probabilitas $>0,05$, maka Distribusi adalah normal.

data hasil pretes dan postes dengan tujuan untuk mengetahui apakah variansinya sama atau tidak antara kelas eksperimen dan kelas kontrol dengan bantuan software SPSS. Uji homogenitas yang digunakan dalam penelitian ini adalah uji Levene. Perumusan hipotesis yang digunakan pada uji homogenitas data pretes dan postes adalah sebagai berikut:

H0 : Tidak terdapat perbedaan varians antara kelas eksperimen dengan kelas kontrol.

H1 : Terdapat perbedaan varians antara kelas eksperimen dengan kelas kontrol.

Dengan menggunakan taraf signifikansi 0,05 maka kriteria pengujiannya adalah:

1. Nilai signifikansi (sig.) atau nilai probabilitas $<0,05$, maka data berasal dari populasi-populasi yang mempunyai varians tidak sama.

2. Nilai signifikansi (sig.) atau nilai probabilitas $<0,05$, maka data berasal dari populasi-populasi yang mempunyai varians sama. 
Hipotesis yang digunakan pada pengujian perbedaan dua rata-rata pretes adalah sebagai berikut.

H0 : Tidak terdapat perbedaan rata-rata kemampuan awal yang signifikan antara kelas eksperimen dan kelas kontrol.

H1: Terdapat perbedaan rata-rata kemampuan awal yang signifikan antara kelas eksperimen dan kelas kontrol.

a) Jika normalitas dan homogenitas dipenuhi, maka uji perbedaan dua rata-rata yang dilakukan adalah uji-t (dua pihak) (Sudjana, 2001: 239).

b) Jika normalitas data pretes dipenuhi tetapi tidak homogen, maka dilakukan uji-t' (Sudjana, 2001: 241).

c) Jika normalitas tidak dipenuhi, maka dilakukan uji non-parametrik yaitu uji Mann-Whitney dengan pendekatan kurva normal (Ruseffendi,1998: 401).

Agar memudahkan dalam pengolahan data, maka dalam penelitian ini digunakan bantuan software SPSS. Adapun kriteria pengujian yang menggunakan taraf signifikansi 0,05 adalah:

1. Jika nilai signifikansi lebih besar dari atau sama dengan 0,05 maka H0 diterima.

2. Jika nilai signifikansi lebih kecil dari 0,05 maka H0 ditolak.

Perumusan hipotesis yang digunakan pada pengujian perbedaan dua rata-rata postes adalah sebagai berikut.

H0: Pencapaian kemampuan bernalar matematis siswa kelas eksperimen tidak lebih baik dari kelas kontrol.

H1: Pencapaian kemampuan bernalar matematis siswa kelas eksperimen lebih baik daripada kelas kontrol.

a) Jika normalitas dan homogenitas dipenuhi, maka dilakukan uji-t (satu pihak) (Sudjana, 2001: 239):

b) Jika normalitas dipenuhi tetapi homogenitas tidak dipenuhi, maka dilakukan uji-t' (Sudjana, 2001: 241).

c) Jika normalitas tidak dipenuhi, maka dilakukan uji non-parametrik yaitu uji Mann-Whitney dengan rumus seperti pada pengolahan data pretes. Agar memudahkan dalam pengolahan data, maka penelitian ini menggunakan bantuan software SPSS. Adapun kriteria pengujian yang menggunakan taraf signifikansi 0,05 adalah:

1. Jika $\frac{1}{2}$ nilai signifikansi (sig.) atau probabilitas $>0,05$, maka Ho diterima.

2. Jika $\frac{1}{2}$ nilai signifikansi (sig.) atau probabilitas $<0,05$, maka Ho ditolak.

\section{Hasil dan Pembahasan}

1. Deskripsi Pencapaian Kemampuan Pembelajaran Matematika Siswa

Pengambilan data dimulai tanggal 28 Januari 2014 dengan agenda pengambilan data kemampuan awal siswa baik kelas eksperimen maupun kelas kontrol dengan menggunakan hasil pengerjaan soal pre tes, sedangkan pengambilan data diakhiri pada tanggal 25 Februari 2014 dengan agenda pengambilan data hasil penelitian dengan menggunakan hasil pengerjaan soal post tes.

Pelaksanaan pengambilan data pada kelas eksperimen dan kelas kontrol masingmasing dilakukan selama tiga kali pertemuan/tatap muka di tambah dua kali pertemuan untuk pemberian pre tes dan post tes. Pada setiap pertemuan peneliti di temani oleh 
observer untuk mengamati dan memberikan masukan tentang keterlaksanaan RPP dalam pembelajaran.

Pelaksanaan pembelajaran untuk masing-masing kelas disesuaikan dengan RPP (Lampiran I Instrumen penelitian) yang telah dibuat oleh peneliti.

Pembelajaran untuk kelas eksperimen dilakukan dengan membagi siswa dalam kelompok-kelompok kecil, kemudian memberikan tugas kelompok, dan hasil dari tugas kelompok itu dipaparkan di depan kelas, setelah itu siswa diberikan LKS (Lembar Kerja Siswa). Dalam setiap proses pembelajaran yang berlangsung, siswa diarahkan agar mampu untuk melakukan setiap aspek dari strategi REACT. Upaya pencapaian aspek dari strategi REACT pada masing-masing pertemuan adalah sebagai berikut:

Pertemuan pertama:

Aspek Relating

: - SIswa menyimak konsep tentang matriks sebagai bahan ajar

- Siswa mengaitkan gambaran matriks dengan kehidupan nyata

Aspek Experiencing : - Siswa mengamati susunan rak buku yang ada di perpustakaan.

Aspek Aplying

: - Membuat dalam bentuk hasil pengamatannya.

Aspek Kooperating

: - Guru mempagi siswa menjadi beberapa kelompok kemudian tiap 47 pok mencari contoh-contoh tentang materi pelajaran mengenai matriks.

Aspek Transferring

: - Siswa diajak bertukar pikiran dengan teman lainnya untuk merumuskan hasil dari kegiatan pembelajaran mengenai matriks dalam kehidupan sehari-hari dan jenis-jenis matriks.

Pertemuan ke-dua:

Aspek Relating

: - Siswa menyimak konsep penjumlahan, pengurangan dan perkalian matriks

- Siswa mengaitkannya dengan kehidupan nyata

Aspek Experiencing : - Siswa menjumlahkan, mengurangkan, mengalikan soal-soal matriks yang ada pada latihan.

Aspek Aplying : : - Hasil pengamatan pada pertemuan pertama yang telah dibuat dalam bentuk matriks di kalikan, dijumlahkan, dan atau dikurangkan.

Aspek Kooperating : : Guru membagi siswa menjadi beberapa kelompok kemudian tiap kelompok mencari contoh-contoh tentang materi pelajaran mengenai matriks setelah itu mengoperasikan matriks-matriks tersebut

Aspek Transferring $\quad$ : - Siswa mempersentasikan hasil kerja kelompok di depan kelas

.Pertemuan ke-tiga:

Aspek Relating

: - Siswa menyimak penjelasan tentang determinan dan invers

- Siswa mengaitkannya dengan kehidupan nyata

Aspek Experiencing : - Siswa mencari determinan dan invers matriks yang adalam pada latihan.

Aspek Aplying : - Siswa menyelesainan soal-soal yang berkaitan dengan determinan dan invers. 
Aspek Kooperating $\quad$ : - Guru membagi siswa menjadi beberapa kelompok kemudian tiap kelompok mengerjakan soal-soal yang diberikan oleh guru.

Aspek Transferring : : - Siswa mempersentasikan hasil kerja kelompok di depan kelas

Pada pertemuan pertama, peneliti membentuk beberapa kelompok secara heterogen, kemudian memberika soal latihan. Pada proses kerja kelompok tersebut siswa masih cenderung bekerja sendiri-sendiri sehingga hanya sebagian kecil saja yang dapat menyelesaikan soal latihan yang diberikan. Meskipun peneliti memberikan arahan, tetapi siswa belum menyadari pentingnya bekerja bersama dalam kelompok.

Setelah melihat hasil yang kurang optimal dari tugas pertemuan pertama, peneliti kemudian membentuk kelompok yang baru. Hal tersebut dimaksudkan agar siswa dapat lebih mudah bekerja sama dengan teman kelompoknya. Perubahan kelompok tersebut sesuai dengan yang diinginkan oleh peneliti, karena pada pertemuan kedua siswa mulai dapat mengerjakan tugas kelompok secara bersama-sama.

Pada pertemuan ke-tiga, hampir semua siswa sudah mampu beradaptasi dengan kelompoknya, pekerjaan yang dikerjakan lebih terorganisir. Semua anggota kelompok berpartisipasi dalam mengerjakan tugas kelompok yang diberikan, hal ini terlihat pada diskusi kelompok, hampir semua anggota kelompok mampu menjawab pertanyaan dari kelompok yang lain.

Secara umum pembelajaran dengan strategi REACT bejalan dengan baik. Pembelajaran diawali dengan pemberian apersepsi pada siswa, guru memberikan motivasi kepada motivasi kepada siswa dengan menyampaikan tujuan pembelajaran. Pembelajaran diawali dengan pemberian masalah yang bersifat kontekstual, selain itu guru juga membagi kelompok-kelompok dalam kelas dan memberikan tugas pada kelompok-kelomppok yang ada, serta membimbing setiap kelompok dalam menyelesaikan tugas kelompoknya, salah satu dari kelompok itu kemudian disuruh mengerjakan tugas yang diberikan pada kelompok itu kemudian memberikan penghargaan kepada kelompok yang yang memiliki jawaban yang benar. Selanjutnya guru dan siswa menyimpulkan pelajaran pada hari itu.

Untuk kelas kontrol, pembelajaran dilaksanakan dengan bersumber pada guru. Siswa menerima materi yang disampaikan oleh guru, mencatat materi, sedikit tanya jawab, dan akhiri dengan soal dan pembahasan.

1) Deskripsi Hasil Pretes

Setelah dilakukan pengolahan data skor pretes dan postes pada aspek Penalaran matematis pada kelompok eksperimen dan kontrol, diperoleh hasil pretes didapatkan hasil bahwa nilai tertinggi dan terendah dari kelas eksperimen secara berturut-turut adalah 14 dan 8 dengan mean/rata-rata 10,05 sedangkan untuk kelas kontrol secara berturut-turut adalah 14 dan 6 dengan rata-rata nilai 10,08. Dan hasil pos tes didapatkan hasil bahwa nilai tertinggi dan terendah dari kelas eksperimen secara berturut-turut adalah 92 dan 58 dengan mean/rata-rata 72,41 sedangkan untuk kelas kontrol secara berturut-turut adalah 85 dan 28 dengan rata-rata nilai 63,27 Deskripsi secara lebih lengkap tampak pada tabel 4 berikut ini:

Tabel 5 Data hasil pre tes

\begin{tabular}{|c|c|c|c|c|c|c|c|c|c|c|}
\hline \multicolumn{5}{|c|}{ Kelas Eksperimen } & \multicolumn{5}{|c|}{ Kelas Kontrol } & \multirow{2}{*}{$\begin{array}{c}\text { Skor } \\
\text { Maks. } \\
\text { Ideal }\end{array}$} \\
\hline $\mathrm{N}$ & $X_{\min }$ & $\mathrm{X}_{\max }$ & $\bar{X}$ & S & $\mathrm{N}$ & $\begin{array}{c}\mathrm{X}_{\mathrm{mi}} \\
\mathrm{n}\end{array}$ & $\mathrm{X}_{\max }$ & $\overline{\bar{X}}$ & $S$ & \\
\hline 37 & 8 & 14 & 10,05 & 1,67 & 3 & 6 & 14 & 10,0 & 1,86 & 100 \\
\hline
\end{tabular}




\section{$7 \quad 8$}

2) Deskripsi Hasil Postes

Pada bagian ini akan diuraikan tentang hasil pretes dan postes siswa pada masing-masing kelas, yaitu kelas eksperimen (REACT) dan kelas kontrol (konvensional).

Berdasarkan hasil postes didapatkan hasil bahwa nilai tertinggi dan terendah dari kelas eksperimen secara berturut-turut adalah 92 dan 58 dengan mean/rata-rata 72,41 sedangkan untuk kelas kontrol secara berturut-turut adalah 85 dan 28 dengan rata-rata nilai 63,27. Deskripsi secara lebih lengkap tampak pada tabel 5 berikut ini:

Tabel 5 Data Hasil Pos tes

\begin{tabular}{|c|c|c|c|c|c|c|c|c|c|c|}
\hline \multicolumn{5}{|c|}{ Kelas Eksperimen } & \multicolumn{5}{|c|}{ Kelas Kontrol } & Skor \\
\hline $\mathrm{N}$ & $X_{\min }$ & $\mathrm{X}_{\max }$ & $\bar{X}$ & $S$ & $\mathrm{~N}$ & $X_{\min }$ & $X_{\max }$ & $\bar{X}$ & $\mathrm{~S}$ & $\begin{array}{c}\text { Maks. } \\
\text { Ideal }\end{array}$ \\
\hline 37 & 58 & 92 & 72,41 & 10,11 & 37 & 28 & 85 & 63,27 & 11,32 & 100 \\
\hline
\end{tabular}

Berdasarkan data pada tabel 5 didapat bahwa kelas eksperimen memiliki ratarata yang lebih tinggi dari pada kelas kontrol.

Nilai gain pada kelas eksperimen berkriteria sedang dan tinggi tapi pada kelas kontrol ada satu nilai gain yang berkriteria rendah. Untuk mengetahui bahwa peningkatan kemampuan bernalar matematis siswa kelompok eksperimen lebih baik dari kelompok kontrol, maka akan digunakan uji perbedaan rata-rata data skor gain tes kemampuan pemecahan masalah matematik. Setelah dilakukan uji normalitas dan homogenitas pada skor gain tes kemampuan pemecahan masalah, maka uji perbedaan rata- rata yang digunakan adalah uji t. Berikut hasil uji perbedaan rata-rata pada skor gain tes kemampuan bernalar matematis siswa:

Tabel 6 Uji t Perbedaan rata-rata skor Gain Kemampuan Penalaran Matematis

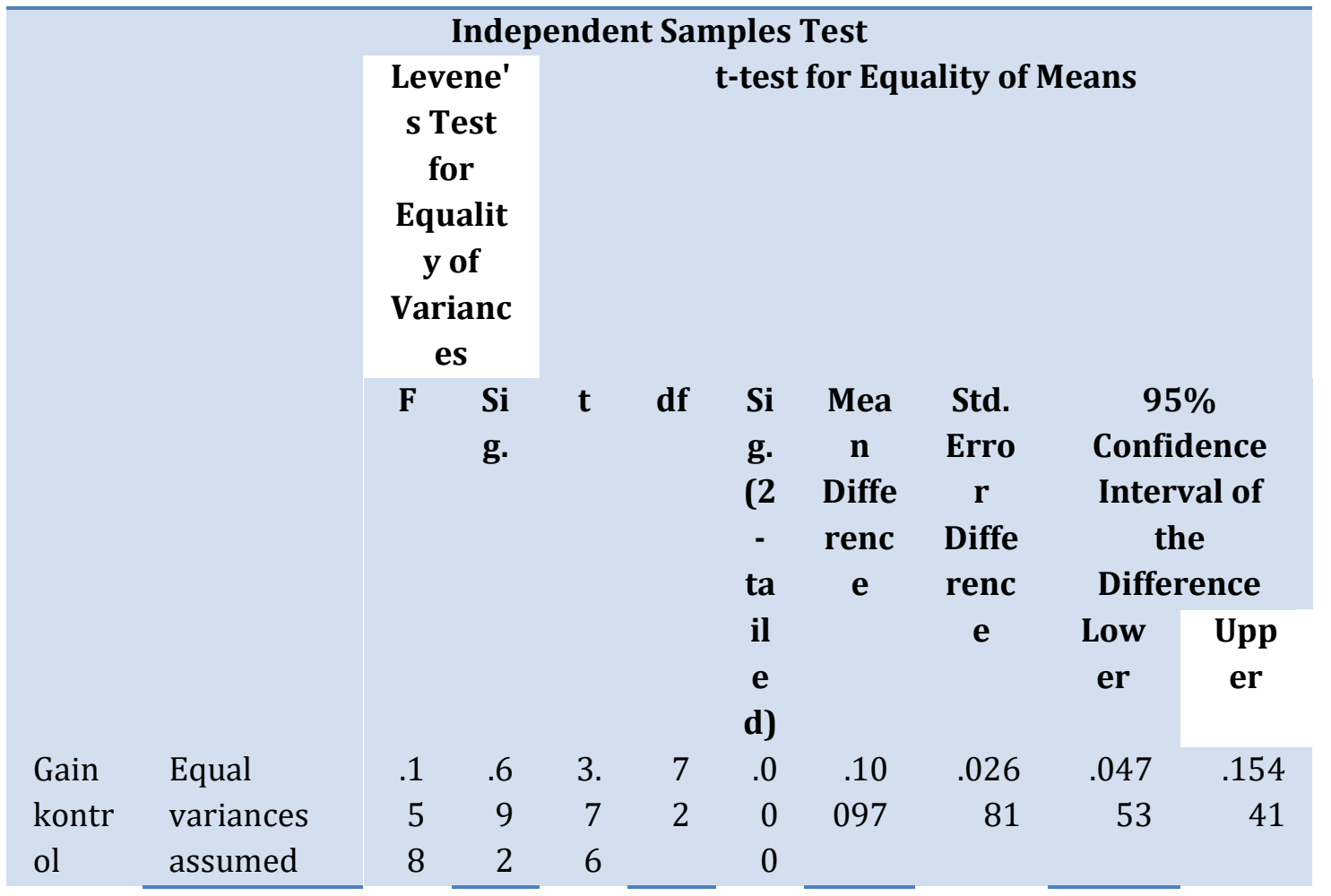




\begin{tabular}{l|l|r|r|r|r|r|r|r}
\hline dan & & 6 & & & & & & \\
eksp & Equal & 3. & 7 & .0 & .10 & .026 & .047 & .154 \\
erim & variances & 7 & 1. & 0 & 097 & 81 & 52 & 42 \\
en & not & 6 & 4 & 0 & & & & \\
& assumed & 6 & 8 & & & & & \\
& & & 0 & & & & & \\
\hline
\end{tabular}

Berdasarkan Tabel 6 diperoleh nilai Asymp.Sig (2-tailed) untuk data penalaran matematis siswa untuk skor gain sebesar 0,00. Hubungan nilai signifikansi Asym.Sig(1tailed $)=$ Asym. Sig(2-tailed) sehingga nilai Asym. Sig(1-tailed $)=0,000$. Jika diambil $=$ 0,05 maka Asymp.Sig(1-tailed) $<0,05$ sehingga Ho ditolak. Kesimpulannya, peningkatan kemampuan penalaran matematis siswa melalui strategi REACT lebih baik daripada siswa yang pembelajarannya konvensional.

2. Deskripsi Respon Siswa Pada Pembelajaran REACT dan Konvensional

1) Skala Sikap

Pemberian skala sikap bertujuan untuk mengetahui respon dan minat siswa terhadap pelajaran matematika, pembelajaran dengan strategi REACT, serta soal-soal kemampuan pemahaman dan pemecahan masalah matematik.

Tabel 7 Distribusi Skor Sikap Siswa untuk Semua Aspek Pembelajaran

\begin{tabular}{|c|c|c|c|c|c|c|}
\hline \multirow[t]{2}{*}{ Aspek } & \multirow[t]{2}{*}{$\begin{array}{c}\text { No } \\
\text { Pernyata } \\
\text { an }\end{array}$} & \multirow[t]{2}{*}{$\begin{array}{c}\text { Sifat } \\
\text { Pernyataa } \\
\text { n }\end{array}$} & \multicolumn{2}{|c|}{ Jawaban } & \multicolumn{2}{|c|}{$\begin{array}{c}\text { Persentase } \\
\text { jawaban } \\
\text { (\%) }\end{array}$} \\
\hline & & & $\mathrm{Ya}$ & $\begin{array}{c}\mathrm{Td} \\
\mathrm{k}\end{array}$ & $\mathrm{Ya}$ & $\mathrm{Tdk}$ \\
\hline \multirow{3}{*}{$\begin{array}{l}\text { Pendapat siswa } \\
\text { terhadap pelajaran } \\
\text { matematika }\end{array}$} & 1 & Positif & 21 & 16 & 56.8 & 43.2 \\
\hline & 2 & Positif & 33 & 4 & 89.2 & 10.8 \\
\hline & 6 & Negatif & 1 & 36 & 2.7 & 97.3 \\
\hline \multirow{5}{*}{$\begin{array}{c}\text { Pendapat terhadap } \\
\text { pembelajaran } \\
\text { REACT }\end{array}$} & 3 & Positif & 17 & 20 & 45.9 & 54 \\
\hline & 7 & Negatif & 11 & 26 & 29.7 & 70.3 \\
\hline & 8 & Negatif & 9 & 28 & 26 & 75.7 \\
\hline & 5 & Positif & 35 & 2 & 99 & 5.4 \\
\hline & 9 & Negatif & 35 & 2 & 99 & 5.4 \\
\hline $\begin{array}{c}\text { Pendapat terhadap } \\
\text { soal-soal }\end{array}$ & 4 & Positif & 9 & 28 & 26 & 75.7 \\
\hline $\begin{array}{c}\text { kemampuan } \\
\text { penalaran } \\
\text { matematis }\end{array}$ & 10 & Negatif & 17 & 20 & 45.9 & 54 \\
\hline
\end{tabular}

Berdasarkan tabel 7 di atas diketahui sebagian besar siswa senang belajar matematika, itu ditunjukkan dari pendapat siswa terhadap pelajaran matematika dimana ada 56,8\% yang senang belajar matematika terlihat pada pernyataan nomor 1 , dan presentase siswa yang senang pada pelajaran matematika yaitu sekitar 89,2\% yang senang hadir pada saat ada pelajaran matematika dan hanya 10,8 yang malas hadir pada saat ada pelajaran matematika seperti terlihat pada pernyataan nomor 2 , sedangkan 
pada pernyataan nomor 6 terlihat bahwa ada 97\% yang tidak akan membuat alasan asalkan siswa itu tidak masuk belajar matematika.

Dari tabel 7 juga dapat kita lihat pendapat siswa terhadap pembelajaran REACT, persentase siswa yang mengerti pembelajaran matematika setelah pembelajaran REACT hanya $45,9 \%$, jika dibandingkan dengan persentase siswa yang tidak mengerti pelajaran matematika setelah pembelajaran REACT yaitu $54,1 \%$, tapi pada pertanyaan nomor 7 dimana pernyataannya yaitu strategi REACT dalam belajar matematika membuat siswa merasa bosan diperoleh persentase jawaban tidak oleh 70,3\% siswa dan hanya ada $29,7 \%$ yang menjawab iya. Persentase pernyataan yang mengatakan pembelajaran REACT tidak cocok dilakukan pada pembelajaran matematika adalah $24,3 \%$ dan yang mengatakan cocok ada 75,7\%. Pada saat pemberian contoh soal pada pembelajaran pun, persentase siswa yang menyatakan berusaha untuk mengerjakannya adalah $94,6 \%$ siswa.

Berdasarkan tabel 7 juga dapat diketahui pendapat siswa terhadap soal-soal kemampuan penalaran matematis, pada pernyataan nomor 4 persentase siswa yang tidak mampu menafsirkan dengan cepat soal-soal cerita yang yang diberikan adalah sekitar 75,7\%, meskipun pada pernyataan selanjutnya mereka menyatakan mempunyai gagasan atau gambaran masalah matetmatika tersebut.

\section{2) Hasil Observasi}

Secara umum pembelajaran dengan strategi REACT berjalan dengan baik. Pembelajaran diawali dengan pemberian apersepsi pada siswa, guru memberikan motivasi kepada siswa dengan menyampaikan tujuan pembelajaran. Pembelajaran diawali dengan pemberian masalah yang bersifat kontekstual, selain itu guru juga membagi kelompok-kelompok dalam kelas dan memberikan tugas pada kelompokkelompok yang ada, serta membimbing setiap kelompok dalam menyelesaikan tugas kelompoknya, salah satu dari kelompok disuruh mengerjakan tugas yang diberikan pada kelompok itu kemudian memberikan penghargaan kepada kelompok yang memiliki jawaban yang benar. Selanjutnya, guru dan siswa menyimpulkan pelajaran pada hari itu.

Sedangkan pada kelas kontrol atau yang menggunakan pembelajaran kontekstual disajikan dengan menggunakan LKS yang terlebih dahulu telah dibagikan kepada siswa. Selanjutnya diawal pembelajaran siswa diminta mengerjakan LKS yang telah diberikan, diberikan pekerjaan rumah, dan dalam proses pembelajaran guru menyelingi dengan pertanyan kepada siswa.

\section{Hasil Analisis Uji Hipotesis}

\section{Prasyarat Analisis}

\section{a. Uji Distribusi Normal}

Pada tabel dibawah ini disajikan hasil uji normalitas dari hasil pretes siswa masing-masing kelompok kelas dengan menggunakan uji normalitas one-sample kolmogorov-Smirnov test dengan menggunakan SPSS. 20 Data hasil uji distribusi normal pada pretes siswa pada masing-masing kelas tampak pada Tabel 8 berikut ini:

Tabel 8 Hasil Uji Normalitaas Pre tes

\begin{tabular}{ccc}
\hline Kelas & Taraf signifikansi & Keterangan \\
\hline Kelas Eksperimen & 0,000 & Tidak Terdistribusi Normal \\
Kelas Kontrol & 0,005 & Tidak Terdistribusi Normal \\
\hline
\end{tabular}




\section{b. Uji Homogenitas Varians}

Berikut ini merupakan deskripsi hasil dari uji homogenitas varian terhadap hasil pretes dan postes siswa pada masing-masing kelas dengan menggunakan software SPSS 20. Data hasil uji-levence dengan menggunakan software SPSS terhadap hasil pretes pada tabel 9 berikut ini:

Tabel 9 Hasil Uji Homogenitas Varians Pre Tes dengan Levence Tes

\begin{tabular}{cccc}
\hline Data & Df & P & Kesimpulan \\
\hline Pre tes & 72 & 0,592 & Varians homogen \\
\hline
\end{tabular}

Berdasarkan data pada tabel 8 dan tabel 9, maka syarat untuk dilakukannya penelitian dengan menggunakan kedua kelas tersebut terpenuhi, sehingga penelitian dilanjutkan dengan menggunakan kedua kelas tersebut sebagai obyek penelitian.

Untuk mengetahui apakah data hasil postes menyebar secara normal dan berasal dari data yang variannya homogen dilakukan uji dengan menggunakan uji distribusi normal dan Levence, dan hasil uji dengan menggunakan software SPSS 20 tampak pada tabel 10 dan tabel 11 berikut:

Tabel 10 Hasil Uji Normalitas Pos Tes

\begin{tabular}{lll}
\hline Kelas & Taraf signifikansi & Keterangan \\
\hline Kelas Eksperimen & 0,054 & Terdistribusi Normal \\
Kelas Kontrol & 0,210 & Terdistribusi Normal \\
\hline
\end{tabular}

Tabel 11 Hasil Uji Homogenitas Varians pos tes dengan levence tes

\begin{tabular}{llll}
\hline Data & Df & P & Kesimpulan \\
\hline Pos tes & 72 & 0,570 & Varians homogen \\
\hline
\end{tabular}

\section{Hasil Uji}

a. Pengujian Terhadap perbedaan rata-rata pre tes

Bagian ini mendeskripsikan tentang perbedaan rata-rata pre tes antara kelas eksperiment yakni kelas yang diberikan pembelajaran REACT dan kelas kontrol yakni yang diberikan pembelajaran konvensional berdasarkan hasil pretes yang telah dikerjakan.

Pengujian dilakukan dengan menggunakan uji mann-whiteney dengan menggunakan bantuan software SPSS. Hasil analisis yang telah dilakukan adalah seperti tampak pada Tabel 12 berikut ini:

Tabel 12 Uji Mann-Whitney Pre Tes Kemampuan Penalaran Matematis

\begin{tabular}{llllll}
\hline Kelompok & $\begin{array}{l}\text { Mann- } \\
\text { whitney }\end{array}$ & $\mathbf{Z}$ & $\begin{array}{l}\text { Asy.sig } \\
(\mathbf{2 -} \\
\text { tailed) }\end{array}$ & kesimpulan & keterangan \\
& & & Ho Diterima & $\begin{array}{l}\text { Tidak } \\
\text { terdapat } \\
\text { perbedaan }\end{array}$ \\
\hline $\begin{array}{l}\text { Eksperimen } \\
\text { Kontrol }\end{array}$ & 677,000 & $-0,085$ & 0,932 & & \\
& & & & & \\
\hline
\end{tabular}


Artinya pre tes antara kelas kontrol dan kelas eksperimen tidak terdapat perbedaan yang signifikan.

\section{b. Pengujian terhadap perbedaan dua rata-rata (uji satu pihak) data hasil postes kelas eksperimen dan kelas kontrol}

Bagian ini mendeskripsikan tentang perbedaan rata-rata pos tes antara kelas eksperimen yakni kelas yang diberikan pembelajaran REACT dan kelas kontrol yakni yang diberikan pembelajaran konvensional berdasarkan hasil pretes yang telah dikerjakan.

Pengujian dilakukan dengan menggunakan uji $t$ dengan menggunakan bantuan software SPSS. Hasil analisis yang telah dilakukan adalah seperti tampak pada Tabel 40 berikut ini:

Karena nilai $1 / 2$ sig. (2-tailed) < dari 0,5 maka Ho di terima, artinya pencapaian kemampuan bernalar matematis siswa kelas eksperimen lebih baik daripada kelas kontrol.

4. Pembahasan

Pada bagian ini akan diuraikan pembahasan hasil dari penelitian secara keseluruhan.

Hasil pretes menunjukkan bahwa nilai tertinggi kelas eksperimen dengan kelas kontrol sama, yaitu 14 tapi nilai terendahnya tidak berbeda jauh, yaitu pada kelas eksperimen nilainya adalah 8 dan pada kelas control nilainya adalah 6 ini mengakibatkan adanya perbedaan pada rata-rata hasil pretes. Kelas eksperimen memiliki rata-rata 10,05 sedang kelas kontrol 10,08 ini menunjukkan bahwa adanya perbedaan kemampuan antara kelas eksperimen dengan kelas kontrol namun kedua kelas masih memiliki variansi yang homogen ditunjukkan oleh hasil uji homogenitas varians diantara keduanya yang memberikan hasil bahwa kedua kelas adalah homogeny, sehingga kedua kelas masih memenuhi untuk dijadikan sebagai obyek penelitian.

Hasil postes menunjukkan bahwa nilai tertinggi dan terendah yang dicapai oleh siswa pada kelas eksperimen secara berturut-turut adalah 92 dan 58 dengan mean/ratarata 72,41 sedangkan untuk kelas kontrol secara berturut-turut adalah 85 dan 28 dengan mean / rata-rata 63,27 (tabel 7).

Dilihat dari rata-rata hasil pretes dan postes masing-masing kelas didapatkan bahwa kelas eksperimen mengalami kenaikan yang cukup besar sedangkan kelas kontrol hampir tidak terlihat adanya perbedaan hasil.

Uji mann-whitney pre tes kelas eksperimen dan kelas kontrol pada table 12 menunjukkan bahwa tidak terdapat perbedaan yang signifikan antara keduanya. Sedangkan uji t yang dilakukan pada pos tes kelas eksperimen dan kelas kontrol pada table 40 menunjukkan bahwa pencapaian kemampuan bernalar matematis siswa kelas eksperimen lebih baik daripada kelas kontrol dimana $1 / 2$ sig. (2-tailed) $<0,05$.

Uji-t yang dilakukan terhadap hasil gain kelas kontrol dan kelas eksperimen menunjukkan adanya perbedaan hasil yang cukup signifikan antara kelaas eksperimen dan kelas kontrol seperti yang tampak pada table 6. Sehingga dapat di simpulkan bahwa terjadi perbedaan penalaran matematis antara kelas eksperimen dan kelas kontrol, dimana kelas eksperimen menggunakan strategi REACT dan kelas kontrol menggunakan strategi konvensional.

Proses pembelajaran dengan menggunakan pendekatan REACT menjadikan siswa menjadi lebih mampu berpartisipasi dalam pembelajaran,siswa menjadi lebih aktif secara 
fisik, aktif dalam berkomunikasi dalam kelompok, siswa menjadi lebih tahu inti dari pembelajaran yang mereka lakukan dengan adanya kesimpulan, siswa menjadi lebih mampu dalam menyelesaikan masalah-masalah yang berkaitan dengan materi, serta kesan senang dalam pembelajaran lebih terlihat. sedang pembelajaran dengan menggunakan pendekatan pendekatan konvensional menjadikan peran guru sangatlah dominan didalam kelas, dan siswa menjadi kurang aktif, siswa hanya mengikuti kehendak guru baik apa yang ditulis maupun apa yang telah disampaikan guru, suasana kelas yang terkesan "sunyi" menjadi sangat dominan dalam kelas, meskipun dalam pelaksanaan pembelajaran siswa juga telah diberi waktu untuk aktif dalam bertanya, akan tetapi hasilnya pembelajaran tetaplah terkesan "sunyi".

Hal ini dimungkinkan karena pembelajaran telah berubah dari paradigma pembelajaran yang berpusat pada guru kepada pembelajaran yang menekankan pada keaktifan siswa untuk mengkonstruksi pengetahuannya sendiri. Temuan ini sesuai dengan pernyataan Crawford (2001) yang menyatakan bahwa strategi REACT memiliki kelebihan diantaranya dapat memperdalam pemahaman siswa serta membuat belajar menyeluruh dan menyenangkan. Strategi REACT juga sesuai dengan pandangan konstruktivisme yang menurut Hudoyo (1998) berorientasi pada investigasi dan penemuan yang pada dasarnya adalah pemecahan masalah. Lebih lanjut, temuan ini juga dimungkinkan karena pembelajaran dengan strategi REACT terdiri dari lima strategi yang satu sama lain mendukung siswa untuk belajar aktif sehingga terbangun suatu kondisi belajar yang kondusif. Lima strategi tersebut adalah relating (mengaitkan), experiencing (mengalami, applying (menerapkan), cooperating (bekerjasama), transferring (mentransfer). Hudoyo (1979) yang mengutip pendapat Ausebel (1971) menyatakan bahwa bahan pelajaran haruslah bermakna, cocok dengan kemampuan siswa dan haruslah relevan dengan struktur kognitif yang dimiliki siswa.

Pelajaran baru haruslah dikaitkan dengan konsep-konsep yang telah ada hingga materi pelajaran yang sedang dipelajari, maknanya dapat dengan cepat dipahami dan diserap. Siswa didorong untuk mengembangkan kemampuan pemahaman dan pemecahan masalah melalui kegiatan menemukan makna, memecahkan masalah dalam kegiatan yang aktif dan berusaha memecahkan masalah non rutin atau mentransfer pengetahuan matematika yang telah dipahami. Kegiatan pembelajaran berlangsung melalui proses pengajuan pertanyaan pemicu yang dimaksudkan untuk mengungkapkan pemahaman siswa atas materi pelajaran yang telah dipelajari, mendorong siswa supaya terlibat aktif dalam kegiatan pembelajaran, dan mengembangkan pemahaman konsep matematika yang telah dipahami oleh siswa. Dari hasil pembahasan dapat disimpulkan bahwa kemampuan pemahaman dan pemecahan masalah matematik dengan pembelajaran strategi REACT lebih baik dari pada siswa yang pembelajarannya secara konvensional dengan kualitas peningkatan sedang. Temuan ini.

Uraian tentang proses pembelajaran tersebut sesuai dengan apa yang diungkapkan oleh Dave Meier yang menyatakan bahwa pembelajaran konvensional cenderung membuat orang menjadi tidak aktif secara fisik dan belajar pun akan melambat bahkan mungkin akan berhenti sama sekali.

Berdasarkan hasil angket, diperoleh informasi bahwa pembelajaran melalui strategi REACT mendapat respon positif dari siswa. Respon dan minat siswa terhadap pelajaran matematika juga baik. Begitu pula dengan respon mereka terhadap soal-soal pemahaman dan pemecahan masalah yang diberikan. Aktivitas belajar yang baik dan munculnya respon 
dan minat yang positif terhadap pembelajaran dengan strategi REACT menguatkan motivasi siswa untuk meningkatkan kemampuannya. Kondisi ini juga memberikan kontribusi positif terhadap peningkatan kemampuan pemahaman dan pemecahan masalah siswa yang belajar dengan strategi REACT. Hal ini sesuai dengan pernyataan Ruseffendi (1991) bahwa sikap positif terhadap matematika dapat berkorelasi dengan prestasi belajarnya.

\section{Penutup}

\section{Kesimpulan}

Berdasarkan penelitian yang telah dilaksanakan dapat diambil kesimpulan sebagai berikut:

1. Kemampuan penalaran siswa pada pembelajaran dengan strategi REACT lebih baik daripada kemampuan penalaran siswa dengan menggunakan strategi konvensional;

2. Terjadi peningkatan kemampuan penalaran matematis siswa yang menggunakan strategi REACT dibandingkan dengan kemampuan penalaran matematis siswa yang menggunakan strategi konvensional;

3. Pembelajaran matematika dengan menggunakan strategi REACT mendapat respon yang lebih baik daripada pembelajaran matematika dengan menggunakan strategi konvensional

2. Saran

Adapun saran-saran yang dapat diberikan adalah sebagai berikut :

1. Kemungkinan adanya kendala-kendala pelaksanaan pembelajaran melalui strategi REACT pada awal pembelajaran perlu diantisipasi oleh guru, diantaranya siswa tidak terbiasa dengan belajar mandiri, mengkonstruksi pengetahuan sendiri dan melatih penalan matematis siswa. Guru disarankan agar membantu siswa mengatasi masalah. Sedangkan untuk kendala siswa tidak terbiasa berdiskusi dalam kelas, disarankan agar guru bisa terus memotivasi siswa dan menciptakan lingkungan yang kondusif untuk itu;

2. Dalam hal ini penelitian dilakukan hanya terbatas untuk meningkatkan kemampuan penalaran matematis. Ada baiknya peneliti selanjutnya dapat menerapkan strategi REACT untuk meningkatkan kemampuan matematika lainnya seperti penalaran, komunikasi, representasi dan koneksi matematik;

3. Disarankan untuk menggunakan strategi REACT pada topik-topik hasan yang esensial saja, karena proses pembelajaran melalui strategi $R E A$ ᄂ . ıemerlukan waktu yang lama.

4. Perlu dilakukan penelitian lebih lanjut mengenai pendekatan REACT bila dibandingkan dengan pendekatan-pendekatan pembelajaran yang lain.

\section{DAFTAR PUSTAKA}

Begle, E. G, 1979. Critical Variabels in Mathematics Educations: finding from a survay of the empirical literature. Washington D. C: Mc. Graw Hill Company.

Crawford, L.M. 2001. Teching Contekstually, Research, Rasionale, and Tecniques for Improving Tudent Motivation And Achievement in Mathematics and Science. Waco, Texas CCI Publishibg, Inc

Haling, Abdul. 2006. Belajar dan Pembelajaran, Universitas Negeri Makassar : Makassar Hamruni. 2012. Strategi Pembelajaran. Insan MadaniYogyakarta.

Hudoyo, Herman. 1990. Strategi Belajar Matematika. IKIP Malang. 
Ilyas, Baharuddin, \& Tiro, Muhammad Arif. 2009. Statistika Terapan untuk Ilmu Ekonomi dan Ilmu Sosial. Makassar: Andhira Publisher.

Lie, Anita. 2005. Cooperatve Learning. Jakarta. Grasindo

Mustakim, Zaenal. Strategi dan Metode Pembelajaran. Pekalongan: STAIN Press.

Nurahman, Iman.. 2011. "Pembelajaran Kooperatif Tipe Team-Accelerated Instruction (TAI) Untuk Meningkatkan Kemampuan Penalaran dan Komunikasi Matematika Siswa SMP”. Pasundan Journal of Mathematics Education Jurnal. 1, (1), 96-130.

Ruseffendi, E. T. 1991. Pengantar kepada Membantu Guru Mengembangkan Kompetensinya dalam Pengajaran Matematika untuk Meningkatkan CBSA. Bandung: Tarsito.

Slameto. 1995. Belajar dan Faktor-Faktor yang mempengaruhinya. Jakarta: Rineka Cipta.

Sudjana. 2001. Teori-Teori Belajar untuk Pengajaran. Bandung: Sinar Baru.

Suherman, Erman, dkk.. 2003. Strategi Pembelajaran Matematika Kontemporer. Bandung: JICA- Universitas Pendidikan Indonesia.

Sumarna Surapranata. 2004. Analisis, Validitas, Realibilitas, dan Interpretasi Hasil Tes. Bandung: PT Remaja Rosdakarya.

Syaifurrahman. 2013. Manajemen dalam Pembelajaran. Jakarta: Indeks

Yaniawati, R. Poppy. 2010. e-learr 66 ternatif Pembelajaran Kontemporer. Bandung: Arfino Raya. 